\title{
Fetal Outcomes of Anti-epileptic Drug Use in Pregnancy: Teratologic
} Approach

\author{
Gebelikte Anti-epileptik İlaç Kullanımının Fetal Sonuçları: Teratolojik Yaklaşım
}

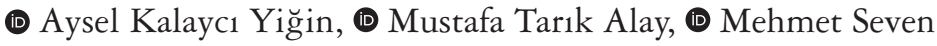 \\ Istanbul University-Cerrahpasa, Cerrahpasa Faculty of Medicine, Department of Medical Genetics, Istanbul, Turkey
}

\begin{abstract}
Objective: To examine the fetal effects of valproic acid (VPA) and carbamazepine (CBZ) used as monotherapy during pregnancy, to determine the anomalies, and to compare them with a control group and previous literature.

Materials and Methods: The data of 10,562 pregnant women who presented to our outpatient clinic between 2009 and 2018 for teratologic consultation were reviewed retrospectively. The study group consisted of 95 pregnant women (VPA: $n=49, C B Z: n=46$ ) who were followed up with the diagnosis of epilepsy and who used VPA or CBZ only as monotherapy during pregnancy. The control group was composed of 88 pregnant women in the same age group, who had no chronic disease, were not expected to cause an increased risk in the first trimester, and used short-term risk group B drugs due to different health problems.

Results: The difference between the prevalence of major, minor anomalies, and behavioral defects between pregnant women using VPA and the control group was statistically significant $(\mathrm{p}<0.044, \mathrm{p}<0.001, \mathrm{p}<0.001$, respectively). The frequency of minor anomalies was statistically significant between pregnant women using $\mathrm{CBZ}$ and the control group, but there was no statistically significant relationship between major anomalies and behavioral defects $(\mathrm{p}=0.116, \mathrm{p}<0.018, \mathrm{p}=0.116$, respectively). Despite receiving anti-epileptic treatment during pregnancy, the frequency of major and minor anomalies in pregnant women who had two or more seizures compared to the control group.

Conclusion: Increasing the anomaly frequency of both epileptic attacks and anti-epileptic treatment constitutes a severe handicap for pregnant women. In teratologic counseling in patients with epilepsy, especially in the first trimester of pregnancy, combined treatment should be avoided if possible and a single antiepileptic drug with the least adverse effects should be chosen. If this is not medically possible, dose adjustment should be made to the most effective and lowest dose and it is recommended to continue mono/combination therapy.
\end{abstract}

Keywords: Epilepsy, valproic acid, carbamazepine, teratologic counseling

Öz

Amaç: Bu çalışmada, valproik asit (VPA) veya karbamazepini (CBZ) monoterapi şeklinde kullanan gebelerde bu ilaçların fetal etkilerinin teratolojik bakış açısıyla incelenmesi, bebeklerde meydana gelen anomalilerin tespit edilmesi ve bulguların kontrol grubuyla ve önceki literatür verileriyle karşılaştırılması hedeflenmiştir. Gereç ve Yöntem: Polikliniğimize teratolojik danışma amacıyla 2009-2018 yılları arasında başvuran ve teratolojik danışma raporu düzenlenmiş olan 10.562 gebenin dosyaları retrospektif olarak incelendi. Çalışma grubu, epilepsi tanısıyla izlenen ve gebelik döneminde sadece monoterapi şeklinde VPA veya CBZ kullanan 95 gebeden (VPA: 49, CBZ: 46) oluşturuldu. Kontrol grubu, benzer yaş grubunda olup, herhangi bir kronik hastalı̆̆ı bulunmayan, değişik sağlık sorunları nedeniyle ilk trimesterde risk artışına yol açması beklenmeyen kısa süreli B risk grubu ilaç kullanan 88 gebeden oluşturuldu.

Bulgular: VPA kullanan gebeler ile kontrol grubu arasında majör-minör anomali ve davranış kusuru görülme sıklı̆̆ açısından istatistiksel olarak anlamlı fark saptand1 (sırasıyla; $\mathrm{p}<0,044, \mathrm{p}<0,001$ ve $\mathrm{p}<0,001$ ). CBZ kullanan gebeler ile kontrol grubu arasında minör anomalilerin sıklığ1 açısından istatistiksel olarak anlamlı fark bulunurken, majör anomaliler ve davranış kusuru arasında istatistiksel olarak anlamlı bir ilişki saptanmadı $(\operatorname{sirasıyla;~} \mathrm{p}=0,116, \mathrm{p}<0,018$ ve $\mathrm{p}<0,116)$. Gebelikte anti-epileptik tedavi almasına rağmen, iki veya daha fazla nöbet geçiren gebelerde majör ve minör anomali sıklı̆̆ 1 kontrol grubuna göre anlamlı olarak fazla saptanırken, davranış kusuru açısından anlamlı bir fark saptanmadı ( $\mathrm{p}>0,05)$.

Sonuç: Epileptik atakların/anti-epileptik tedavinin anomali sıklı̆̆ını artırması gebelerde önemli bir handikap oluşturmaktadır. Teratolojik danışmada; epileptik hastalarda gebeliğin planlanarak yapılması, özellikle gebeliğin ilk trimesterinde kombine tedaviden sakınılması ve yan etkisi en az olan tek bir ilacın tercih edilmesi, şayet bu tıbben mümkün değilse doz ayarlaması yapılarak en etkili ve en düşük dozda mono/kombine tedaviye devam edilmesi önerilmektedir.

Anahtar Kelimeler: Epilepsi, valproik asit, karbamazepin, teratolojik danışma

Address for Correspondence/Yazışma Adresi: Mehmet Seven MD, Istanbul University-Cerrahpasa, Cerrahpasa Faculty of Medicine, Department of Medical Genetics, Istanbul, Turkey

Phone: +90 2124143000 - 68351 E-mail: mimseven@istanbul.edu.tr ORCID: orcid.org/0000-0001-7878-2039

Received/Geliş Tarihi: 02.06.2020 Accepted/Kabul Tarihi: 25.12.2020

${ }^{\circ}$ Copyright 2021 by Turkish Neurological Society

Turkish Journal of Neurology published by Galenos Publishing House. 


\section{Introduction}

Teratology is a branch of science that examines structural and functional changes in the embryo caused by factors such as drugs used by pregnant women and exposure to radiation or infectious agents during pregnancy. Factors involved in this change are called teratogens. Teratogens are held responsible for about $7-10 \%$ of congenital defects (1). Congenital anomalies can be grouped under two subtitles; major and minor. Major anomalies are generally associated with exposures to teratogens during organogenesis $(2,3,4,5)$, and their prevalence in the population has been reported as $2-3 \%(2,3)$. Major anomalies require surgical intervention, whereas minor anomalies are of cosmetic significance only. However, the coexistence of several minor anomalies may be a sign of the presence of a major anomaly (4).

Patients with epilepsy constitute $0.3-0.5 \%$ of all pregnant women (6). Therefore, the need for anti-epileptic treatment is common during pregnancy. The thought that anti-epileptic treatment may affect the fetus is an important cause of anxiety in expectant mothers (2). In many studies conducted to date, it has been shown that single or combined anti-epileptic therapy during pregnancy increases the risk of congenital anomalies $(7,8)$. Valproic acid (VPA) and/or carbamazepine (CBZ) is most commonly used in anti-epileptic treatment, and congenital anomalies are mostly seen in the children of pregnant women using these drugs (9). The frequency of congenital anomalies increases even more in those receiving combined therapy (10). The complex of anomalies in the fetuses of mothers using VPA during pregnancy is called "fetal valproate syndrome". In this syndrome, facial findings such as small, flat nose; and flat nasal arch; small and abnormal ears; epicanthus; hypertelorism; high, wide forehead; and frontal stenosis are often seen, and the frequency of neural tube defects (NTD), heart, kidney, and extremity anomalies also increases $(11,12)$. The complex of anomalies that occurs with the use of CBZ is called "CBZ embryopathy". In this embryopathy, findings such as pre-postnatal growth retardation, microcephaly, bifrontal stenosis, epicanthus, upward-curved palpebral fissure, short nose accompanied by long filtrum, hypoplastic nails, cardiac and/or renal anomalies, and cleft palate are observed (13). It is known that folic acid deficiency plays an important role in the formation of NTD, orofacial clefts, and limb defects. CBZ and VPA are effective through folic acid-dependent pathways (4). It has been reported that when CBZ and VPA are used in combination, the frequency of congenital malformations increases 10-fold (14). It has been shown that the use of folic acid during pregnancy reduces the rate of congenital anomalies by $30-85 \%(15,16)$.

In our country, no study has examined the use of anti-epileptic drugs (AEDs) during pregnancy and their fetal effects from a teratologic point of view. Existing studies are rather descriptive and contain limited patient data. In this retrospective study, the children of mothers who were referred to our center for teratologic consultation using CBZ or VPA as monotherapy during pregnancy and who had a teratologic consultation report were evaluated with a teratologic approach and the fetal effects of anti-epileptic treatment were analyzed in comparison with a control group.

\section{Materials and Methods}

Files of 10,562 pregnant women who were admitted to our center for teratologic consultations between 2009 and 2018 were retrospectively reviewed. The study group was composed of 95 pregnant women (VPA: $n=49, C B Z: n=46$ ) who were followed up with the diagnosis of epilepsy and were referred to our center due to the use of VPA or CBZ as monotherapy during pregnancy and for whom a teratologic consultation report was prepared. Pregnant women who used AEDs due to various health problems but did not have epilepsy, pregnant women who received combined antiepileptic treatment, who did not receive CBZ or VPA treatment or in whom the treatment was discontinued, changed or new treatment was added in the first trimester of pregnancy, even if CBZ or VPA treatment was started in the pre-pregnancy period, were not included in the study. The control group consisted of 88 pregnant women of similar age with no chronic diseases, who were referred to our center due to short-term use of B risk group drugs due to various health problems that were not expected to increase the risk in the first trimester and for whom a teratologic consultation report was prepared. This study was conducted in accordance with the Declaration of Helsinki and with the permission of the University of Health Sciences, Istanbul Training and Research Hospital Clinical Research Ethics Committee (2011KAEK-50).

\section{Data Collection}

Personal information of all pregnant women included in the study were recorded, including the control group gestational age according to the beginning of the last menstrual period of the expectant mother; gestational age according to ultrasound; drugs used in pregnancy and their indications for use; time of use; duration, dose, and food and drug administration category; whether there was radiation exposure, and if there was radiation exposure, the dose of radiation to which the fetus was exposed; whether they had habits such as smoking and alcohol use; heavy metal and chemical substance exposure; whether they had a viral or bacterial infection during pregnancy; whether they had a chronic disease; whether they used folic acid or multivitamin preparations; the education status of the mother and the father; what kind of job they worked; the kinship status of the spouses; their personal history, the reasons for marriage if there was a kinship; and whether they had any health problems during pregnancy. Expectant mothers who were given teratological consultations were recommended to bring their children to our outpatient clinic for examination within the first month after birth.

\section{Postpartum Examinations}

All newborns were invited to our center for examinations after birth. During the examination, whether the mother had an epileptic seizure during pregnancy; the frequency, type, severity and duration of the seizures; the trimester in which the seizures occurred; whether the mother had any additional health problems during pregnancy (preeclampsia, eclampsia, diabetes mellitus, hypertension), and whether the mother used any drug other than AEDs, whether the prenatal follow-ups were regular, and whether there were any problems encountered during and after delivery were questioned and recorded. The birth week of the newborn, the type of delivery, whether the newborn was born at term, anthropometric measurements (height, weight, head circumference) in the postpartum period and during the examination were recorded. The newborns were evaluated in terms of dysmorphism and systemic examinations were performed by a pediatric geneticist. 
Genetic/biochemical/psychometric/radiologic tests were recommended for newborns with indications. The children suspected of having behavioral disorders during their follow-up were evaluated by child psychiatrists. The findings of the babies/ children who could not be brought for examination after birth, which were recorded in other centers, were obtained by phone.

\section{Statistical Analysis}

All statistical analyses of the study were performed using the SPSS 25.0 program. Descriptive statistics are given as numbers and percentages for categorical variables, and as mean (standard deviation) for numerical variables. The chi-square test was used in the comparison of categorical variables, and the Mann-Whitney U and Kruskal-Wallis tests were used in the comparison of numerical variables. Statistically, $\mathrm{p}<0.05$ was considered significant.

\section{Results}

The mean age of pregnant women in the study group using VPA was $28.76 \pm 4.63$ (range, 18-40) years, and their husbands' mean age was $30.06 \pm 3.15$ (range, $24-38$ ) years. It was determined that $9(18.4 \%)$ of the pregnant women used cigarettes, $2(4.1 \%)$ used alcohol, $6(12.2 \%)$ of the spouses used cigarettes, and none used alcohol. None of the pregnant women and spouses used illicit drugs. There was no history of in vitro fertilization (IVF). Twenty-seven $(55.1 \%)$ of the pregnant women were primary school graduates, $22(44.9 \%)$ were secondary school graduates, 44 $(89.8 \%)$ were housewives, and $5(10.2 \%)$ were businesswomen. Consanguineous marriage was present in 9 women $(18.4 \%)$ (Table 1). Eighteen $(36.7 \%)$ of the pregnancies were planned and $31(63.39 \%)$ were random (Table 1$)$. Sixteen $(32.7 \%)$ of the deliveries were performed via the vaginal route, and $29(59.1 \%)$ by cesarean. Two (4.1\%) pregnancies resulted in spontaneous abortion, and $2(4.1 \%)$ were terminated electively. Six (12.2\%) pregnant women used multivitamins and 39 (79.6\%) used folic acid. In addition, $6(12.2 \%)$ pregnant women were found to have seizures under treatment (Table 2). The average daily dose of VPA was $336.49 \pm 362.65 \mathrm{mg}$ and the cumulative dose was calculated as $89.993 .88 \pm 96.991 .84 \mathrm{mg}$. The mean gestation period was $39.04 \pm 1.2$ weeks (Table 3 ). The mean anthropometric measurements of the newborns postpartum were as follows: Height was $49.68 \pm 2.12 \mathrm{~cm}$, weight was $3.190 \pm 0.488 \mathrm{~kg}$, and head circumference was $34.76 \pm 1.26 \mathrm{~cm}$ (Table 4). Three children of the pregnant women in this group were found to have major anomalies, 9 had minor anomalies, and 8 had behavioral disorders. Major and minor anomalies were seen together in two children. One of these children had behavioral defects and it was found that her mother had seizures 3 times during pregnancy. One of the three children with major anomalies had microcephaly, one had pelvicalyceal ectasia and anal stenosis, and the other had patent ductus arteriosus.

The ages of the pregnant women in the study group who used CBZ were between 19-40 years and the ages of their spouses were between $24-43$ years. The mean age was determined as $28.3 \pm 4.86$ and $30.07 \pm 4.19$ years, respectively. Smoking was present in 12 $(26.1 \%)$ pregnant women and alcohol use in $2(4.3 \%)$ pregnant women. Eight $(17.4 \%)$ of their spouses were using cigarettes and $2(4.3 \%)$ were using alcohol. There was no use of illicit drugs in the pregnant women and their spouses. There was no history of IVF pregnancy. There were $22(47.8 \%)$ pregnant women who were primary school graduates, and $24(52.2 \%)$ were high school or above graduates. Thirty-three $(71.77 \%)$ of the pregnant women were housewives and $13(28.23 \%)$ were businesswomen.

Table 1. Demographic data of study and control groups

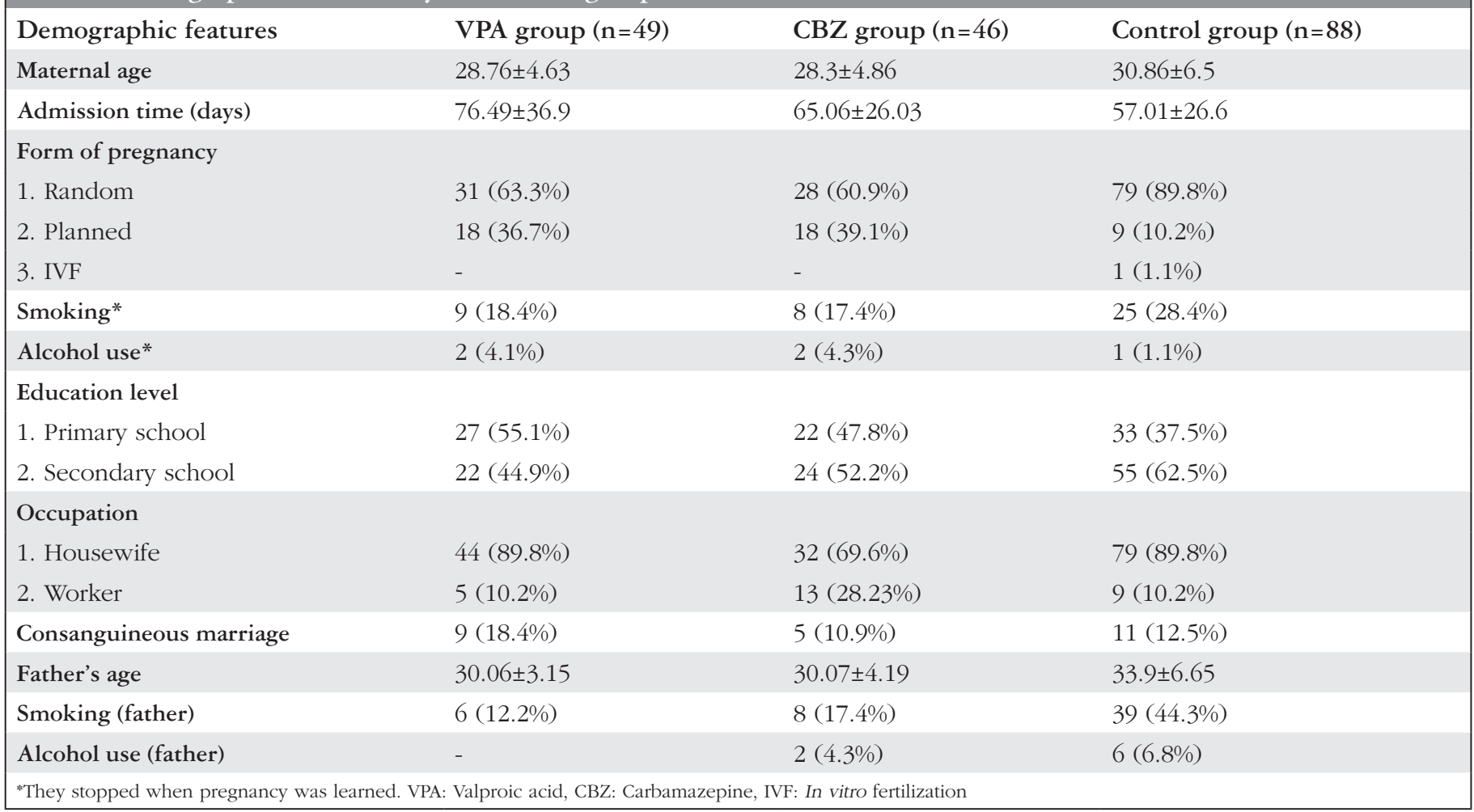


Consanguineous marriage was present in five (10.9\%) (Table 1). Eighteen $(39.1 \%)$ of the pregnancies were planned and $28(60.9 \%)$ were random (Table 1$)$. Thirteen $(28.3 \%)$ of the deliveries were performed via the vaginal route and $32(69.6 \%)$ by cesarean. One $(2.2 \%)$ pregnancy resulted in elective termination. There was no spontaneous abortion. Five (10.9\%) pregnant women used multivitamins and $34(73.9 \%)$ used folic acid (Table 2). In addition, $6(13 \%)$ pregnant women had seizures under treatment. The cumulative dose of CBZ was 74.240.91 $\pm 68.541 .28 \mathrm{mg}$ and the mean daily dose was $154.58 \pm 108.20 \mathrm{mg}$. The mean gestational period was $38.05 \pm 3.03$ weeks (Table 3 ). The mean anthropometric measurements of infants postpartum were as follows: Height was $48.6 \pm 4.1 \mathrm{~cm}$, weight was $3.111 \pm 0.567 \mathrm{~kg}$, and head circumference was $34.98 \pm 2.05 \mathrm{~cm}$ (Table 4 ). Two children of the pregnant women in this group had major anomalies, five had minor anomalies, and two had behavioral disorders. Major and minor anomalies were sen together in 2 of these children. The mother of one stated that she had a seizure during pregnancy. A minor anomaly was observed in one of the 2 children with behavioral defects, and no major or minor anomalies were found in the other. One of the 2 children with major anomalies had spina bifida and the other had hypospadias (Table 5). Chromosome analysis was requested from patients with one major anomaly or with more than two minor anomalies, and no chromosomal anomalies were found as a result of the analysis.

The age range of pregnant women in the control group was between 18-46 years, and their husbands between 22-53 years. The mean age was determined as $30.86 \pm 6.5$ and $33.9 \pm 6.65$ years, respectively. Smoking was present in 25 (28.4\%) pregnant women and alcohol use in one $(1.1 \%)$ pregnant woman. Thirtynine $(44.3 \%)$ of their husbands were using cigarettes and $6(6.8 \%)$ were using alcohol. There was no illicit drug use in pregnant women or their spouses. There was no history of IVF pregnancy. There were $33(37.5 \%)$ pregnant women who were primary school graduates and $55(62.5 \%)$ were high school or above graduates. Seventy-nine of them (89.8\%) were housewives and nine $(10.2 \%)$ were working in a job. Consanguineous marriage was present in $11(12.5 \%)$ pregnant women (Table 1$)$. Nine of the pregnancies $(10.2 \%)$ were planned and $79(89.8 \%)$ were random (Table 1$)$. Fifty-four $(67 \%)$ of the deliveries were via the vaginal route and 28 $(33 \%)$ by cesarean. One $(1.1 \%)$ pregnancy resulted in spontaneous abortion and $5(5.7 \%)$ resulted in elective termination. Twenty-

\begin{tabular}{|llll|}
\hline Table 2. Pregnancy follow-up and results & & & \\
Type of pregnancy & VPA group $(\mathbf{n}=49)$ & CBZ group (n=46) & Control group (n=88) \\
Normal birth & $16(32.7 \%)$ & $13(28.3 \%)$ & $54(61.4 \%)$ \\
Caesarian & $29(59.1 \%)$ & $32(69.6 \%)$ & $28(31.8 \%)$ \\
Spontaneous abortion & $2(4.1 \%)$ & 0 & $1(1.1 \%)$ \\
Elective termination & $2(4.1 \%)$ & $1(2.2 \%)$ & $5(5.7 \%)$ \\
History of epileptic seizures during pregnancy) & $6(12.2 \%)$ & $6(13 \%)$ & - \\
Use of folic acid & $39(79.6 \%)$ & $34(73.9 \%)$ & $9(10.2 \%)$ \\
Multivitamin use & $6(12.2 \%)$ & $5(10.9 \%)$ & $27(30.7 \%)$ \\
VPA: Valproic acid, CBZ: Carbamazepine & & & \\
\hline
\end{tabular}

Table 3. Evaluation of the patient's drug dose and duration

\begin{tabular}{llc} 
Average daily usage time (average, SD) & $65.06 \pm 26.4$ \\
Cumulative dose, mg (mean, SD) & $115.49 \pm 100.03$ & $74.240 .91 \pm 68.541 .28$ \\
Drug dose used per day, mg (mean, SD) & $89.993 \pm 96.991$ & $154.58 \pm 108.20$ \\
Medication durations (trimester) & $336.49 \pm 362.65$ & $2043.5 \%)$ \\
- First & $29(59.2 \%)$ & $5(10.9 \%)$ \\
- First and second & $16(32.6 \%)$ & $21(45.7 \%)$ \\
- First, second and third & $4(8.1 \%)$ & \\
VPA: Valproic acid, CBZ: Carbamazepine, SD: Standard deviation & & \\
\hline
\end{tabular}

Table 4. Newborn anthropometric measurements

\section{Birth information}

Week of birth (mean, SD)

Birth size (mean, SD)

Birth weight (mean, SD)

Head circumference (mean, SD)

VPA: Valproic acid, CBZ: Carbamazepine, SD: Standard deviation

\section{VPA group $(\mathrm{n}=49)$}

$39.04 \pm 1.2$

$49.68 \pm 2.12$

$3190.45 \pm 487.75$

$34.76 \pm 1.26$
VPA group $(\mathrm{n}=49)$

$115.49 \pm 100.03$

CBZ group $(n=46) \quad$ Control group $(n=88)$

$38.05 \pm 3.03$

$48.6 \pm 4.1$

$3111 \pm 567.07$

$34.98 \pm 2.05$
$38.9 \pm 1.4(34-42)$

$49.5 \pm 1.35(47-52)$

$3314 \pm 308.027(2,500-4,000)$

$34.5 \pm 0.93(32-37)$ 
seven $(30.7 \%)$ pregnant women used multivitamins and $9(10.2 \%)$ used folic acid (Table 2). The mean anthropometric measurements of newborns postpartum were as follows: Height was $49.5 \pm 1.35$ $\mathrm{cm}$, weight was $3.314 \pm 0.308 \mathrm{~kg}$, and head circumference was $34.5 \pm 0.93 \mathrm{~cm}$ (Table 4).

The difference in terms of the prevalence of major and minor anomalies and behavioral defects between pregnant women using VPA and the control group was statistically significant $(\mathrm{p}<0.044$, $\mathrm{p}<0.001$, and $\mathrm{p}<0.001$, respectively). There was a statistically significant difference in terms of frequency of minor anomalies between pregnant women using CBZ and the control group, but no statistically significant difference was found in terms of major anomalies and behavioral defects $(\mathrm{p}=0.116, \mathrm{p}=0.018$, and $\mathrm{p}=0.116$, respectively) (Table 5).

\section{Discussion}

The basic principles of teratology were first put forward in the 1970 s and these principles were formulated as, "the teratogenic effect may vary according to the dose of the drug exposed, the duration of action, the fetal period it affects, the interaction of the agent with the environment and the response of the individual to these effects". Teratologic counseling is performed to inform the pregnant women and specialists who follow the pregnancy based on the literature information on the possible effects of teratogenic agents/drugs on the fetus before and/or during pregnancy. Studies have shown that teratologic counseling given routinely to pregnant women plays an important role in reducing the incidence of structural and functional anomalies (17).

VPA and CBZ are the leading AEDs that increase the possibility of developing structural and functional anomalies and are known to be teratogenic. In studies conducted with pregnant women who received monotherapy, it was reported that the most common AED causing structural defects and behavioral disorders was VPA (10). It is stated that the effect of VPA is dose-dependent. The frequency of congenital malformations increases at doses of $1000 \mathrm{mg}$ or above compared with low doses. In a study conducted by the United Kingdom Pregnancy Register, it was shown that pregnant women using VPA [6.2\%; 95\% confidence interval (CI): 4.6-8.2\%] had an approximately three times higher risk of major congenital malformation (MCM) compared with pregnant women using CBZ $(2.2 \%, 95 \% \mathrm{CI}: 1.4-3.4 \%)$, [odds ratio (OR): 2.78 $(\mathrm{p}<0.001)$, OR: $2.97(\mathrm{p}<0.001)]$. In the same study, congenital malformation was observed in one $(9.1 \%)$ of 10 pregnant women using VPA more than $1000 \mathrm{mg}$ /day, and one (5.1\%) of 20 pregnant women using low dose (95\% CI: 5.8-14.1\%) (18).

According to the study conducted by the North American Pregnancy Registry, the rate of major birth defects in pregnant women using VPA as monotherapy was $10.7 \%$, and this rate was $2.8 \%$ in pregnant women using other monotherapy regimens. The rate of MCM in the community was determined as $1.6 \%$ (19). According to this study, it was observed that the use of VPA during pregnancy increased the MCM rate by approximately four

Table 5. Comparison of control and study groups in terms of major and minor anomalies and behavioral disorders and distribution of anomalies

VPA group $(n=49)$

CBZ group $(n=46)$

Control group $(\mathrm{n}=88)$

$\begin{array}{lll}\text { Major finding } & & \\ \text { Number of patients affected } & 3(6.1 \%) & 2(4.4 \%) \\ \text { Significance value } & \mathrm{p}=0.044 & \mathrm{p}=0.116 \\ \text { Number of findings } & 4 & 2\end{array}$

Patent ductus arteriosus (1)

Anal stenosis (1)

Results Microcephaly (1)

Spina bifida occulta (1)

Pelvicalyceal ectasia (1)

Hypospadias (1)

\section{Minor finding}

Number of patients affected

$10(20.4 \%)$

$5(10.8 \%)$

Significance value

$\mathrm{p}<0.001$

Number of findings

15

$\mathrm{p}=0.018$

$\begin{array}{ll} & \text { Hypertelorism (5) } \\ & \text { Frontal bossing (2) } \\ & \text { Clinodactyly (2) } \\ \text { Findings } & \text { Strabismus (2) } \\ & \text { Bitemporal stenosis (1) } \\ & \text { Hemangioma (1) } \\ & \text { Simian line (1) } \\ & \text { Syndactyly (1) }\end{array}$

$\begin{array}{llr}\text { Behavioral disorder } & 8(16.3 \%) & 2(4.4 \%) \\ \text { Significance value } & \mathrm{p}<0.001 & \mathrm{p}=0.116 \\ \text { *Study groups were compared based on the control group. VPA: Valproic acid, CBZ: Carbamazepine }\end{array}$

Flatness of nasal root (3)

Hypertelorism (3)

Hemangioma (2)

Simian line (2)

Synophrys (2)

Long philtrum (2)

Brachydactyly (1)

Thin upper lip (1)

Hypertrichosis (1)

Significance value

$8(16.3 \%)$

$2(4.4 \%)$

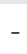

$-$

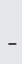

1

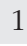

*

1

Hemangioma (1)

Study groups were compared based on the control group. VPA: Valproic acid, CBZ: Carbamazepin 
times (95\% CI: $2.1-7.4 \%)$. In a study conducted in Australia, it was shown that pregnant women using VPA at a dose of $1100 \mathrm{mg}$ or above carried an approximately 10 times higher risk of MCM compared with pregnant women using VPA below the dose of $1100 \mathrm{mg}(20,21)$. In a study conducted in Finland, 857 pregnant women using AEDs were evaluated and 263 were found to use VPA and 805 used CBZ. Pregnant women with epilepsy who received anti-epileptic treatment in the first trimester were compared with those who did not, and it was determined that the use of CBZ increased the risk of congenital anomalies by 1.27 times (95\% CI: $0.72-2.23$ ), and VPA by four times. It was determined that the use of VPA at a dosage above $1500 \mathrm{mg}$ /day caused an approximately 11fold increase in risk (OR: 10.89, 95\% CI: 2.90-34.3), and a dosage below $1500 \mathrm{mg} /$ day an approximately four-fold increase in risk [OR: 3.68, 95\% CI: (1.97-6.86); $\mathrm{p}<0.001]$. No dose-dependent relationship was found in CBZ users. It is also thought that the use of AEDs might reduce the incidence of malformations when VPA is excluded. However, combined therapies appear to increase the risk of malformations, with or without VPA exclusion (10).

In studies conducted until 2005, it was shown that the use of VPA increased the risk of congenital malformation by nine times (OR: 8.6, 95\% CI: 7.3-10.1). In another study conducted on pregnant women using VPA (37,154 patients and 39,472 controls), the frequency of congenital malformation was three times higher. In another study, it was found that the risk of congenital malformation increased by approximately six-fold in pregnant women using VPA as monotherapy at a dosage of $700 \mathrm{mg} /$ day or less (OR: 5.9, 95\% CI: 4.2-8.3), and by 11-fold in those using a dose of $700-1500 \mathrm{mg}$ (OR: $11.0,95 \% \mathrm{CI}: 8.8-13.8$ ), and by 24-fold (OR: $24.095 \%$ CI: 16.8-33.1) in those using a dosage of $1500 \mathrm{mg} /$ day or above (22). In a study, no significant relationship was found in terms of the risk of MCM [OR: 1.06, 95\% CI: $(0.68-$ $1.66) ; \mathrm{p}=0.79]$ in patients receiving $\mathrm{CBZ}$ monotherapy, and 2.5fold increased risk of major malformation was found in VPA users [OR: 2.47, 95\% CI: [1.58-3.84]; $\mathrm{p}<0.001)$ (23). In the present study, it was shown that VPA increased the incidence of both major and minor congenital malformations. When pregnant women using VPA were classified as below $1.000 \mathrm{mg} /$ day or above users, no statistically significant difference was found between them $(p<0.05)$. This may be due to the cumulative dose calculation, the folic acid use of the majority of the pregnant women using AEDs or the number of samples.

It has been reported that limb, genitourinary, and cardiovascular system anomalies and NTD are frequently encountered in pregnant women using AEDs as monotherapy (10). In a study conducted in England, pregnant women using VPA, CBZ, and lamotrigine were evaluated in terms of the frequency of major congenital malformation. NTDs were found in $1.1 \%$ of VPA users and $0.2 \%$ of CBZ users; cleft palate in $1.1 \%$ of VPA users and $0.2 \%$ of CBZ users; cardiac defects in $1.1 \%$ of VPA users and $0.8 \%$ of CBZ users; genitourinary defects in $1.2 \%$ of VPA users and $0.3 \%$ of CBZ users; and skeletal system anomalies were found in $0.8 \%$ of VPA users and $0.2 \%$ of CBZ users (24).

Although many major-minor anomalies related to VPA syndrome have been described in the literature, no patient has yet been encountered in which all these anomalies were seen together. Among the defects detected in children of pregnant women using VPA to date; microcephaly, spina bifida, ventricular septal defect, atrial septal defect, Fallot tetralogy, pulmonary atresia, hypoplastic left heart, cleft palate, diaphragmatic hernia, gastroschisis, hypospadias in men, polydactyly, clubfoot, and craniosynostosis are included. Among these, cardiac anomalies, limb defects, genitourinary system anomalies, and NTDs occupy an important place (25). A meta-analysis showed that the use of VPA, phenytoin, and phenobarbital significantly increased the risk of congenital malformations, but the increased risk was less in the use of $\mathrm{CBZ}$ and lamotrigine, and the same study found that AEDs most frequently caused cardiovascular and skeletal system defects. In that study, a statistically significant increase was found in the incidence of inguinal hernia, face/neck/ear anomalies, and cleft palate in pregnant women using AEDs (10).

In the present study, the association of pelvicalyceal ectasia and anal stenosis was found in the group using VPA. In the literature, anal stenosis has not been reported in the children of women using VPA during pregnancy. Anal stenosis often occurs due to acquired or rarely congenital causes. Another reason that may be associated with congenital anal stenosis is primary infections during pregnancy (26). In our study, the mother of the child with anal stenosis stated that she did not have any infection during pregnancy and did not smoke or drink alcohol. In addition, there are many syndromes associated with anal stenosis (e.g. Townes Brock, Axenfeld Rieger, Bartosocopas Papas syndromes, and VACTERL association). In our patient, it was considered as isolated anal stenosis because clinical findings suggesting these syndromes were not observed. The anal stenosis seen in our patient may be due to VPA use or coincidental during pregnancy. More case reports are needed to decide whether this finding is due to VPA use. Urogenital anomalies associated with VPA use are frequently seen and these anomalies include pelvicalyceal ectasia and hydronephrosis. On the other hand, one of the two major anomalies seen in pregnant women using CBZ is NTD and the other is hypospadias. Urogenital anomalies are common in both groups.

The incidence of NTD is $0.1-0.5 \%$. This rate has increased 10-20 times in pregnant women using VPA (27) and 2-10 times in pregnant women using CBZ (28). In our study, NTD was not observed in VPA users and was observed in only one newborn using CBZ. There was no history of folic acid use in this newborn with NTD. Thirty-nine (79.6\%) of the 49 pregnant women using VPA stated that they used folic acid, $6(12.6 \%)$ used multivitamins, and $34(73.9 \%)$ of 46 pregnant women using CBZ stated that they used folic acid, 5 (10.9\%) used multivitamins. Studies have shown that the use of folic acid and/or multivitamins during pregnancy significantly reduces the incidence of NTD. The absence of NTD in the group using VPA may be due to the use of folic acid and/or multivitamins or the small number of patients. Our finding was in accordance with the literature that the use of folic acid and/ or multivitamins during pregnancy was effective in reducing the frequency of NTD.

Another important factor that plays a role in the formation of developmental anomalies is the age of the mother. Pregnancies over the age of 35 years pose an important risk like a teratogen in the development of congenital anomalies. In the study group, four women using VPA and four using CBZ and 27 pregnant women in the control group were found to be aged 35 years or over. No age-related anomalies or syndromes were found in the children of pregnant women aged over 35 years in the study and control groups. This may be due to the small number of pregnant women aged over 35 years included in the study. 
Smoking and alcohol use during pregnancy are other environmental factors that are considered teratogens. Many anomalies related to smoking during pregnancy have been reported and no specific syndrome has been described. However, it has been reported that smoking during pregnancy is associated with the risk of cleft lip-palate, NTD, gastrointestinal, and cardiac and renal anomalies $(29,30)$. The complex of anomalies related to alcohol use during pregnancy is called "fetal alcohol syndrome (FAS)". FAS is generally seen in children of pregnant women who consume high doses of alcohol continuously (31). In addition, pregnant women smoking and/or drinking alcohol in our study stated that they quit drinking alcohol and smoking when they realized that they were pregnant.

\section{Conclusion}

It is known that AED use in the treatment of epilepsy and epileptic attacks during pregnancy has teratogenic effects. The fact that both epileptic attacks and anti-epileptic treatment increase the frequency of anomalies constitutes an important handicap for pregnant women. It is known that more than $90 \%$ of patients with epilepsy give birth to healthy children, and more than $95 \%$ of pregnant women in society give birth to healthy children. For this reason, expressions against pregnancy in patients with epilepsy should be avoided. In teratologic counseling, it is recommended to plan pregnancy in epileptic patients; avoid combined treatment if possible, especially in the first trimester of pregnancy; choose a single drug with the least adverse effects, and if this is not possible in terms of maternal health, continue mono/combined therapy at the lowest dose by doing effective dose adjustment according to changes in drug-blood levels during pregnancy; and use folic acid to protect against the risk of NTDs caused by AEDs.

\section{Ethics}

Ethics Committee Approval: This study was conducted in accordance with the Declaration of Helsinki and with the permission of the University of Health Sciences, Istanbul Training and Research Hospital Clinical Research Ethics Committee (2011KAEK-50).

Informed Consent: Informed consent forms were obtained from all pregnant women included in the study.

Peer-review: Externally peer-reviewed.

\section{Authorship Contributions}

Surgical and Medical Practices: M.T.A., M.S., Concept: A.K.Y., M.S., Design: A.K.Y., M.S., Data Collection or Processing: M.T.A., Analysis or Interpretation: A.K.Y., M.S., Literature Search: M.T.A., A.K.Y., Writing: A.K.Y., M.T.A., M.S.

Conflict of Interest: No conflict of interest was declared by the authors.

Financial Disclosure: The authors declared that this study received no financial support.

\section{References}

1. Wilson JG. Mechanisms of teratogenesis. In: Persaud TVN, (ed). Problems of birth defects. Springer, Dordrecht: Berlin;1972.

2. Kinney MO, Morrow J. Epilepsy in pregnancy. BMJ 2016;353:i2880.

3. Leppig KA, Werler MM, Cann CI, Cook CA, Holmes LB. Predictive value of minor anomalies. I. Association with major malformations. J Pediatr 1987;110:531-537.

4. Opitz JM, Gilbert-Barness EF. Congenital anomalies: Malformation syndromes. In: Gilbert-Barness EG, ed. Potter's pathology of the fetus and infant. St. Louis:Mosby;1997:323-346.
5. Tomson T, Battino D. Teratogenic effects of antiepileptic drugs. Lancet Neurol 2012;11:803-813.

6. Holmes LB, Harvey EA, Coull BA, et al. The teratogenicity of anticonvulsant drugs. N Engl J Med 2001;344:1132-1138.

7. Betts T, Fox C. Proactive pre-conception counselling for women with epilepsy-is it effective? Seizure 1999;8:322-327.

8. Centers for Disease Control and Prevention (CDC). Update on overall prevalence of major birth defects-Atlanta. Georgia, 1978-2005. JAMA 2008;299:756-758.

9. Artama M, Auvinen A, Raudaskoski T, Isojärvi I, Isojärvi J. Antiepileptic drug use of women with epilepsy and congenital malformations in offspring. Neurology 2005;64:1874-1888.

10. Meador K, Reynolds MW, Crean S, Fahrbach K, Probst C. Pregnancy outcomes in women with epilepsy: a systematic review and meta-analysis of published pregnancy registries and cohorts. Epilepsy Res 2008;81:1-13.

11. Mohd Yunos H, Green A. Fetal valproate syndrome: the Irish experience. Ir J Med Sci 2018;187:965-968.

12. Di Liberti JH, Farndon PA, Dennis NR, Curry CJ. The fetal valproate syndrome. Am J Med Genet 1984;19:473-481.

13. Jones KL, Lacro RV, Johnson KA, Adams J. Pattern of malformations in the children of women treated with carbamazepine during pregnancy. $\mathrm{N}$ Engl J Med 1989;320:1661-1666.

14. Nadebaum C, Anderson V, Vajda F, et al. The Australian brain and cognition and antiepileptic drugs study: IQ in school-aged children exposed to sodium valproate and polytherapy. J Int Neuropsychol Soc 2011;17:133-142.

15. Lumley J, Watson L, Watson M, Bower C. Periconceptional supplementation with folate and/or multivitamins for preventing neural tube defects. Cochrane Database Syst Rev 2001;CD001056

16. Wang H, De Steur H, Chen G, et al. Effectiveness of folic acid fortified flour for prevention of neural tube defects in a high risk region. Nutrients 2016;8:152.

17. Elsinga J, de Jong-Potjer LC, van der Pal-de Bruin KM, et al. The effect of preconception counselling on lifestyle and other behaviour before and during pregnancy. Womens Health Issues 2008;18(Suppl 6):S117-S125.

18. Morrow J, Russell A, Guthrie E, et al. Malformation risks of antiepileptic drugs in pregnancy: a prospective study from the UK Epilepsy and Pregnancy Register. J Neurol Neurosurg Psychiatry 2006;77:193-198.

19. Wyszynski DF, Nambisan M, Surve T, et al. Increased rate of major malformations in offspring exposed to valproate during pregnancy. Neurology 2005;64:961-965.

20. Vajda FJ, O'brien TJ, Hitchcock A, et al. Critical relationship between sodium valproate dose and human teratogenicity: results of the Australian register of anti-epileptic drugs in pregnancy. J Clin Neurosci 2004;11:854858.

21. Pennell PB. Antiepileptic drugs during pregnancy: What is known and which AEDs seem to be safest? Epilepsia 2008;49(Suppl 9):43-55.

22. Tomson T, Battino D, Bonizzoni E, et al. Dose-dependent teratogenicity of valproate in mono- and polytherapy: an observational study. Neurology 2015;85:866-872.

23. Veiby G, Daltveit AK, Engelsen BA, Gilhus NE. Fetal growth restriction and birth defects with newer and older antiepileptic drugs during pregnancy. J Neurol 2014;261:579-588.

24. Campbell E, Kennedy F, Russell A, et al. Malformation risks of antiepileptic drug monotherapies in pregnancy: updated results from the UK and Ireland Epilepsy and Pregnancy Registers. J Neurol Neurosurg Psychiatry 2014;85:1029-1034.

25. Jentink J, Loane MA, Dolk H, et al. Valproic acid monotherapy in pregnancy and major congenital malformations. N Engl J Med 2010;362:2185-2193.

26. Gao XY, Gao PM, Wu SG, et al. Risk factors for congenital anal atresia. Zhongguo Dang Dai Er Ke Za Zhi 2016;18:541-544.

27. Ornoy A. Valproic acid in pregnancy: How much are we endangering the embryo and fetus? Reprod Toxicol 2009:28:1-10.

28. Matlow J, Koren G. Is carbamazepine safe to take during pregnancy? Can Fam Physician 2012;58:163-164.

29. Källén K. Multiple malformations and maternal smoking. Paediatr Perinat Epidemiol 2000;14:227-233.

30. Kelsey JL, Dwyer T, Holford TR, Bracken MB. Maternal smoking and congenital malformations: an epidemiological study. J Epidemiol Community Health 1978;32:102-107.

31. Denny L, Coles S, Blitz R. Fetal alcohol syndrome and fetal alcohol spectrum disorders. Am Fam Physician 2017;96:515-522. 